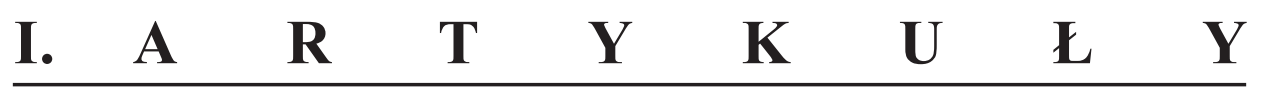

DOI: $10.19195 / 0080-3626.61 .1$

KLAUDIA SOCHA

\title{
REFLEKSJE O WIELOŚCI PERSPEKTYW BADAWCZYCH W STUDIACH NAD DAWNĄ KSIĄŻKĄ DRUKOWANĄ I PRAKTYCZNYCH POŻYTKACH Z TYCH BADAŃ
}

Najnowsze tendencje w badaniach nad starymi drukami. Kształt typograficzny książki. Zachodnie i polskie badania nad książką dawną. Perspektywy badań nad dawną książką i ich praktyczne zastosowanie. dawnej

SŁOWA KLUCZOWE: metodologia badań nad dawną książką, layout (projekt) książki

\section{NAJNOWSZE TENDENCJE W BADANIACH NAD STARYMI DRUKAMI}

W ostatnim czasie praca bibliologa, a zwłaszcza badacza starych druków, uległa zasadniczej zmianie. Osobiste kwerendy w licznych bibliotekach, żmudne porównywanie egzemplarzy, problemy związane z pozyskiwaniem reprodukcji powoli odchodzą w niepamięć. Coraz liczniej powstające repozytoria i biblioteki cyfrowe sprawiają, że mając dostęp do Internetu, badacz może w krótkim czasie wyszukać, ściągnąć na swój dysk i porównać kilka edycji lub nawet egzemplarzy tego samego wydania. Prace związane z digitalizacją zbiorów prowadzone przez biblioteki i archiwa sprawiają, że powstają ogólnie dostępne materiały badawcze. Oczywiście to proces długotrwały, zakrojony na lata. Zanim do sieci trafią wszystkie zasoby bibliotek, skazani jesteśmy na łączenie starszych metod z nowoczesnymi. Równocześnie okazuje się, że zmienia się technologia i standardy, które kiedyś były w pełni wystarczające, dziś już nikogo nie zadowalają. Na przykład mikrofilmy, bardzo często wykorzystywane jako podstawa wykonywania odbitek, teraz nie satysfakcjonują badacza przyzwyczajonego do skanów wykonanych z wysoką rozdzielczością. Zmieniają się także obowiązujące dotychczas formaty plików, ze względu na rozwijające się systemy i oprogramowanie komputerowe. 
To jednak tylko powierzchowne zmiany, w ostatecznym rozrachunku bardzo korzystne, gdyż umożliwiają dostęp do ogromnych zasobów bibliotecznych z całego świata. Problemem staje się nie brak konkretnego egzemplarza, lecz nadmiar materiałów, a właściwie ich wyszukiwanie w tych nieprzebranych zasobach. Niezależnie od zmian technologicznych ciągle aktualne pozostaje pytanie: jak, i co ważniejsze, po co badać dziś zasoby dawnej książki? W dobie książki elektronicznej skupianie się na druku, a zwłaszcza na technologiach już dawno nieużywanych czy rozwiązaniach ograniczonych przez niedoskonałość materiałów, wydaje się niezbyt przydatne. Oczywiście zawsze można przywołać odpowiedź himalaistów pytanych o sens zdobywania górskich szczytów, jednak zasoby ludzkiej kultury materialnej nie tylko stanowią wyzwanie badawcze, lecz mają również wpływ na praktyczne wykorzystanie wiedzy. Rozwijający się coraz śmielej ruch archeologii eksperymentalnej dowodzi, że stosowane w przeszłości przez rzemieślników rozwiązania technologiczne, uznawane przez teoretyków danej dziedziny za oczywiste, wcale tak oczywiste nie są. Nie zawsze można liczyć na świadectwa $z$ epoki: zachowało się nieco traktatów opisujących sposoby działania dawnych mistrzów, ale próba odkrycia wszystkich ich tajemnic zazwyczaj okazuje się daremna. Przekazywanie wiedzy fachowej odbywało się także bezpośrednio, a ta droga, np. w badaniach nad dawnym drukiem, jest dla współczesnych nieodwołalnie zamknięta ze względu na zmiany technologiczne, jakie zaszły w ciągu ostatnich 200 lat. Jedynym sposobem odtworzenia działań dawnych drukarzy są próby rekonstrukcji ich narzędzi, maszyn i metod postępowania. Takie eksperymenty podejmowane są np. w Wielkiej Brytanii, gdzie odtwarza się najstarsze prasy, konserwuje te nowsze maszyny: drukarskie, do składu gorącego i introligatorskie, oraz wskrzesza zapomnianą już niemal sztukę tradycyjnego giserstwa. Ta bardzo ciekawa działalność rzadko jednak uznawana jest za naukową, częściej spychana bywa do niszy działań popularyzujących wiedzę, amatorskich lub wręcz hobbystycznych. Próby te jednak stanowić mogą bardzo dobry punkt wyjścia do zrozumienia związków między materialnym kształtem przedmiotu, jakim jest książka, a technologią. Prócz działań rekonstrukcyjnych badacz dawnych druków dysponuje także naukowymi opracowaniami opartymi na materiałach źródłowych, pozwalającymi prześledzić dokładnie proces powstawania czcionki drukarskiej ${ }^{1}$ oraz sposób działania i ewolucję maszyn ${ }^{2}$. Nie w pełni wykorzystywane są materiały, dzięki którym odtworzyć można proces produkcji, a mianowicie wychodzące już od XVII wieku podręczniki drukarstwa ${ }^{3}$

${ }^{1}$ H. Carter, A View of Early Typography up to about 1600, London 1969; J. Pirożyński, Johannes Gutenberg i poczatki ery druku, Warszawa 2002, czy F. Smeijers, Counterpunch Making Type in the Sixteenth Century, Designing Typefaces Now, London 2011.

2 J. Moran, Printing Presses. History and Development from the Fifteenth Century to Modern Times, London 1973.

3 Najstarszy z nich to dzieło J. Moxona Mechanick Exercises on the Whole Art of Printing (Londyn 1683). Pozostałe z tego najwcześniejszego okresu to m.in. M.D. Fertela La Science 
(w języku polskim taki podręcznik po raz pierwszy ukazał się dopiero $\mathrm{w}$ roku $\left.1832^{4}\right)$.

Jednak technologia to nie wszystko. Każde dzieło ludzkich rąk, także to niezwykle skomplikowane, jakim jest książka, przekaz myśli ludzkiej, stanowi wytwór swojej epoki. Na jego kształt mają wpływ nie tylko materiały i możliwości techniczne drukarza, ale również jego kunszt i wrażliwość estetyczna. Co więcej, bardzo często na książce, na jej projekcie odbija się tzw. gust epoki, a także moda. Decyzje podejmowane przez drukarza niekiedy ściśle odzwierciedlały potrzeby estetyczne odbiorców, ale mogły być również wynikiem jego fascynacji lub doświadczeń zdobytych za granicą. Przepływ prądów i inspiracji estetycznych w Europie thumaczy rozpowszechnianie się różnych nurtów artystycznych lub rozwiązań projektowych. W tej sytuacji świadkiem epoki stają się druki w swej materialnej formie. Dzięki nim można odtworzyć nie tylko migrację motywów, ale również szersze podejście do estetyki danej epoki. Badania nad projektem graficznym pozwalają dotknąć także potrzeb estetycznych szerszych grup społecznych, co przemieszcza zakres badań bibliologicznych na grunt antropologii kulturowej. Takie przesunięcie dziś już nikogo nie dziwi. Badania zjawiska rozpowszechniania się druku oraz panującego wówczas repertuaru wydawniczego w kontekście konfliktów religijnych, odkrywanie powiązań między stanem gospodarki a rozwojem oficyn drukarskich, wpływ decyzji politycznych na popularność różnych zakresów piśmiennictwa ${ }^{5}$ - to przecież tematy podejmowane od lat, pozwalające zobaczyć książkę w kontekście dużo szerszym niż zakreślony przez tradycyjne badania bibliologiczne.

\section{KSZTAŁT TYPOGRAFICZNY KSIĄŻKI}

Wpływ kultury materialnej danej epoki na kształt książki zauważył słynny szwajcarski projektant Adrian Frutiger, który zwrócił uwagę na zbieżność między formą i charakterem liter w różnych epokach a architekturą danego okresu' ${ }^{6}$. Minuskuła karolińska, której proporcje wpisują się doskonale w schemat czteroliniowy, a kształt liter opisany jest głównie na kole i kwadracie lub wyważonym pro-

pratique de l'imprimerie (Saint Omer 1723), Ch.F. Gessnera In der Buchdruckerey wohl unterrichtete Lehrjungen, oder Anfangsgründe der Buchdruckerkunst (Lipsk 1743) oraz najsłynniejszy, połączony z wzornikiem pism, Manuel typographique P.-S. Fourniera (Paryż 1766).

${ }^{4}$ F. Ząbkowski, Teoria sztuki drukarskiej dostosowana do praktyki, Warszawa 1832.

5 Trudno wymienić wszystkie publikacje omawiające powyższe tematy, w tym kontekście najbardziej chyba znanymi są przywołane dalej opracowania L. Febvre'a i H.-J. Martina oraz E. Eisenstein, The Printing Press as an Agent of Change. Communications and Cultural Transformations in Early Modern Europe, t. 1-2, Cambridge 1979, i eadem, Rewolucja Gutenberga, thum. H. Hollender, Warszawa 2004.

6 A. Frutiger, Człowiek i jego znaki, Kraków 2010, s. 132-133. 
stokącie, bardzo silnie nawiązuje do architektury romańskiej, także preferującej te figury geometryczne ${ }^{7}$. Jeszcze ciekawsze wydaje się poszukiwanie wspólnych rozwiązań estetycznych w sztuce gotyckiej, gdyż architektura tego okresu jest dużo bardziej zróżnicowana. Łamana linia pism gotyckich nawiązuje do ostrych łuków i ozdobników architektonicznych, przypomina także gotycki kontrapost, różniący się znacznie od starszych, antycznych wzorów. To nie wszystko: pisma niemieckie, tekstura, a potem fraktura, mają zdecydowanie bardziej łamaną i ostrą formę (obecną także w niemieckim gotyku) niż pisma tego okresu wykształcone po drugiej stronie Alp: włoska rotunda, zaokrąglona, szeroka i harmonijna, bez tendencji do przełamywania krzywizn ${ }^{8}$, inaczej niż jej odpowiedniki w innych częściach Europy, odzwierciedla styl, który bardzo długo zachował wzorce romańskie, a potem płynnie przeszedł $\mathrm{w}$ renesans, omijając gotyk ${ }^{9}$, natomiast bastarda francuska, w swoich fantazyjnych laskach, wyciągniętych dekoracyjnie wydłużeniach górnych i regularnych proporcjach, naśladuje styl francuskich katedr stanowiących niedościgły wzór sztuki gotyckiej ${ }^{10}$. Wyraźne różnice między tymi pismami ukazują różne kanony estetyczne panujące w tym czasie w Europie i są dowodem, że książka może stanowić zwierciadło gustu swojej epoki nie tylko w warstwie słownej, lecz także w swym kształcie zewnętrznym.

Równie widoczne są związki pism drukarskich z kulturą materialną: porównanie zrównoważonych, harmonijnych antykw renesansowych opartych na wzorcach kaligraficznych z dynamicznymi antykwami barokowymi o zmiennej grubości kreski, bardziej dramatycznych proporcjach i wyrazistych, ozdobnych zakończeniach liter przypomina zestawienie spokojnej sylwetki rzymskiej kaplicy Tempietto zbudowanej w 1502 roku według projektu Donata Bramantego z falistą fasadą kościoła S. Carlo alle Quattro Fontane lub rzeźb przedstawiających ten sam motyw młodego Dawida, które powstały w nieco ponad sto lat po sobie. Dzieło Michała Anioła ukazuje spokój, piękno i równowagę, rzeźba Giovanniego Lorenza Berniniego zaś, realizująca założenia innego stylu, jest zatrzymana w ruchu, niespokojna, koncentrująca w sobie energię przedstawionej postaci, co podkreśla układ określany jako figura serpentinata. Można mnożyć podobne przykłady, wiążąc kolejne grupy pism z rozwojem przemysłu silnie przekształcającego kraj-

${ }^{7}$ Por. rzuty architektoniczne budowli, wzory i detale: Architektura. Style i detale, pod. red. E. Cole, Warszawa 2008, s. 184-199, oraz liczne realizacje rotund, półkolistych portali i sklepień kolebkowych: Wielka historia sztuki. T. 1, G. Marrucchi, R. Belcari, Sztuka przedromańska i romańska, Warszawa 2010.

8 A. Gieysztor, Zarys dziejów pisma łacińskiego, Warszawa 2009, s. 129.

9 Zob. W. Koch, Style w architekturze. Arcydzieła budownictwa europejskiego od antyku po czasy wspótczesne, Warszawa 2011, s. 169, oraz B. Borngässer, Architektura gotyku we Włoszech, [w:] Gotyk. Architektura, rzeźba, malarstwo, pod red. R. Tomana, Köln [Kraków] 2007, s. 242.

10 Bastarda, jako dość późny typ pisma, nawiązuje raczej do gotyku późnego, zachowującego jednak główne założenia gotyku dojrzałego, por. Wielka historia sztuki. T. 2, G. Marrucchi, E. Nesti, C. Sirigatti, Sztuka gotycka, Warszawa 2010, s. 25-59. 
obraz i wpływającego na architekturę. Jednak Frutiger posuwa swoje skojarzenia znacznie dalej, wiążąc różne typy skryptów (alfabetów) z architekturą i sztuką używających ich cywilizacji, co pokazał na przykładzie pisma chińskiego oraz pism Azteków i Majów ${ }^{11}$.

\section{ZACHODNIE I POLSKIE BADANIA NAD KSIĄŻKĄ DAWNĄ}

Druk w takim ujęciu staje się nie tylko przedmiotem badań materiałoznawczych lub odtwarzających sam proces powstawania, lecz również projektem, czyli wytworem świadomego działania twórcy — rzemieślnika lub nawet artysty, zakomponowanym intencjonalnie $\mathrm{w}$ duchu danej epoki z poszanowaniem pewnych zasad lub z ich świadomym (albo nie do końca świadomym) odrzuceniem.

Za granicą od lat rozwija się nurt takich badań, w kręgu anglosaskim zwany physical bibliography, przez Francuzów zaś - bibliographie matérielle. Impulsem do ich powstania stały się założenia badawcze wprowadzone w kręgu szkoły wypracowanej przez uczonych związanych z czasopismem „Annales d'Histoire Économique et Sociale". Charakterystyczne dla niej podejście preferujące całościowy ogląd długich okresów historycznych zamiast szeregu pojedynczych zdarzeń oraz postrzeganie zmian jako ewolucji, a nie rewolucji zmieniło sposób patrzenia na historię, także materialną. Metodę tę reprezentowali głównie historycy: Pierre Chaunu ${ }^{12}$, Lucien Febvre, Marc Bloch, Fernand Braudel, François Furet, Emmanuel Le Roy Ladurie, Philippe Ariès, Jacques Le Goff, Georges Duby, Jean Delumeau oraz Jacques Ozouf. Główne cechy typowe dla tej grupy wyróżnił Janusz Gruchała ${ }^{13}$, omawiając problem wpływu szkoły „Annales” na badania nad książką. Szkoła ta preferowała opracowania obejmujące dłuższe odcinki czasu, tzw. koniunktury. Wyniki przedstawiano za pomocą tabel i wykresów, gdyż źródła można było grupować we w miarę jednorodne zbiory i ujmować je liczbowo (kwantytatywność).

Takie podejście pozwalało inaczej spojrzeć na historię książki, toteż dość szybko zaczęły się ukazywać publikacje zawierające wyniki badań z tego kręgu zagadnień. Wśród nich warto wyróżnić dzieło Luciena Febvre’a i Henri-Jeana Martina L'Apparition du livre $\mathrm{z}$ roku $1958^{14}$ oraz opracowania powstałe $\mathrm{w}$ zespole

11 A. Frutiger, op. cit., s. 110-113.

12 P. Chaunu, Cywilizacja wieku oświecenia, tłum. E. Bąkowska, Warszawa 1993; idem, Séville et l'Atlantique (1504 á 1650), Paris 1955-1960, lub idem, Czas reform. Historia religii i cywilizacji (1250-1550), tłum. J. Grosfeld, Warszawa 1989.

13 J.S. Gruchała, Iucunda familia librorum. Humaniści renesansowi w świecie książki, Kraków 2002, s. 26-35.

14 Wydane jako tom 49 serii „L'Évolution de l'Humanité. Synthèse collective” redagowanej przez H. Berra. 
badaczy pod kierownictwem François Fureta (zbiór pt. Livre et société dans la France du $18^{\mathrm{e}}$ siècle ${ }^{15}$ ).

Metoda francuska w połączeniu z doświadczeniami badaczy z kręgu anglosaskiego, gdzie wykształciła się w pierwszych dziesięcioleciach wieku XX „nowa bibliografia" (new bibliography, physical bibliography) ${ }^{16}$, wprowadziła do bibliologii inną perspektywę. Udowodniła, że książka może być postrzegana jako obiekt materialny podlegający wnikliwej analizie. Zainteresowanie to objęło wszystkie elementy budujące książkę, stąd liczne publikacje dokumentujące badania nad materiałami używanymi w jej produkcji oraz poszczególnymi typograficznymi środkami wyrazu. Równocześnie ważne staje się całościowe podejście do tzw. życia książki, obejmującego proces produkcji, dystrybucji i recepcji. Doskonałym przykładem opracowań ukazujących książkę w taki sposób jest 4-tomowe wydanie Histoire de l'édition française ${ }^{17}$. To monumentalne dzieło zawiera artykuły poświęcone szeroko pojętemu rynkowi książki, technologii, ale skupia się także na zagadnieniach szczegółowych, takich jak proces powstawania książki rękopiśmiennej ${ }^{18}$ i drukowanej ${ }^{19}$, forma i struktura inkunabułu ${ }^{20}$, pisma drukarskie ${ }^{21}$, forma i funkcja iluminacji ${ }^{22}$ oraz ilustracji książkowej ${ }^{23}$, materiały drukarskie, np. papier ${ }^{24}$, rozwiązania techniczne i technologiczne ${ }^{25}$, a także estetyka druku oraz zagadnienia typograficzne ${ }^{26}$.

15 Livre et société dans la France du 18 e siècle, t. 1, Paris-La Haye 1965; t. 2, Paris-La Haye 1970.

16 J. Feather, Cross-Channel Currents: Historical Bibliography and „l'histoire du livre”, „The Library” seria 6, t. 2, 1980, nr 1, s. 4.

17 Histoire de l'édition française, pod red. H.-J. Martina, R. Chartiera. T. 1, Le livre conquérant. Du Moyen Âge au milieu de XVII siècle, Paris 1982; T. 2, Le livre triomphant, 1660-1830, Paris 1984; T. 3, Le temps des éditeurs. Du Romantisme à la Belle Époque, Paris 1985; T. 4, Le livre concurrencé, 1900-1950, Paris 1986.

18 J. Vezin, La fabrication du manuscrit, [w:] Histoire de l'édition française..., t. 1, s. 21-51.

19 J. Veyrin-Forrer, Fabriquer un livre au livre au XVI siècle, [w:] Histoire de l'édition française..., t. 1, s. 336-369.

20 A. Labarre, Les incunables : la présentation du livre, [w:] Histoire de l'édition française..., t. 1, s. 228-255.

${ }^{21}$ H.-J. Martin, Les styles typographiques, [w:] Histoire de l'édition française..., t. 2, s. 149 155; S. Le Men, La vigniette et la letter, [w:] Histoire de l'édition française..., t. 3, s. 356-368.

$22 \mathrm{H}$. Toubert, Formes et fonctions de l'enluminure, [w:] Histoire de l'édition française..., t. 1, s. 109-146; M. Melot, Le texte et l'image, [w:] Histoire de l'édition française ..., t. 3, s. 329-355.

23 M. Pastoureau, L'illustration du livre : comprendre ou rêver ?, [w:] Histoire de l'édition française..., t. 1, s. 602-628.

24 A. Chevallier, La matière première : le papier, [w:] Histoire de l'édition française..., t. 2, s. $35-45$.

${ }^{25}$ F. Barbier, Les innovations technologiques, [w:] Histoire de l'édition française..., t. 2, s. 721-729; idem, L'industriallisation des techniques, [w:] Histoire de l'édition française..., t. 3, s. 51-66; D. Renoult, Les nouvelles possibilités techniques : le triomphe de la mécanique, [w:] Histoire de l'édition française..., t. 4, s. 28-50.

${ }^{26}$ F. Barbier, Les formes du livre, [w:] Histoire de l'édition française..., t. 2, s. 757-772; R. Ponot, La creation typographique des Français, [w:] Histoire de l'édition française..., t. 4, s. 367-399; D. Renoult, La mise en page, [w:] Histoire de l'édition française ..., t. 4, s. 400-418. 
Zainteresowanie tematem książki w równie szerokim ujęciu zauważyć można także w Polsce ${ }^{27}$. Między innymi Wydawnictwo Uniwersytetu Warszawskiego wydaje tłumaczenia najważniejszych dzieł badaczy europejskich (czego przykładem mogą być Pismo. Idea i przedstawienie Armanda Petrucciego ${ }^{28}, \mathrm{~Pa}$ pierowy świat Davida R. Olsona ${ }^{29}$, wspomniane już Narodziny ksiażki Luciena Febvre’a i Henri-Jeana Martina ${ }^{30}$ ) oraz bardzo interesujący zapis rozmów przeprowadzonych z francuskimi badaczami przez Pawła Rodaka ${ }^{31}$. Nie brak także opracowań na temat materialnej formy książki. Klasyczne są już opracowania Janusza Sowińskiego ${ }^{32}$ i Zdzisława Staniszewskiego ${ }^{33}$. Również w wydanej ostatnio Encyklopedii książki sporo miejsca poświęcono książce jako przedmiotowi, jej historii, procesowi powstania i funkcjom ${ }^{34}$.

Pytanie, jak badać stare druki, doczekało się już wielu różnych odpowiedzi ${ }^{35}$. Skupienie się na projekcie typograficznym, czyli tzw. layoucie, pozwala zwrócić uwagę na intencjonalne działanie twórcy. Projekt odpowiada również na potrzeby czytelnika, a jego forma zależy nie tylko od rodzaju użytych materiałów, ale i od funkcji. Rozwój funkcjonalnego podejścia do wydawanych książek widać na konkretnych przykładach dawnych druków, np. w pojawieniu się różnych formatów druków, w zależności od przewidywanej sytuacji lektury (np. niewielkie modlitewniki lub książki popularne). Wielu badaczy podkreśla rolę Aldusa Manucju-

27 Badania zagraniczne wpłynęły także na ośrodki polskie, o czym świadczą liczne artykuły omawiające zagadnienia metodologiczne — zob. np. K. Migoń, Nowe modele i nowe osiagnięcia wspótczesnej historiografii książki, „Biuletyn Biblioteki Jagiellońskiej” 38, 1988, s. 227-239; J. Pirożyński, Nowe kierunki w zagranicznych badaniach nad dawna książa, ,Historyka. Studia Metodologiczne” 26, 1996, s. 71-87; K. Migoń, U źródet współczesnej historiografii ksiązki: Kazimierz Piekarski i jego „Ksiązka w Polsce XV i XVI wieku”, „Roczniki Biblioteczne” 53, 2009, s. 23-37.

28 A. Petrucci, Pismo. Idea i przedstawienie, tłum. A. Osmólska-Mętrak, Warszawa 2010.

29 D.R. Olson, Papierowy świat. Pojęciowe i poznawcze implikacje pisania i czytania, tłum. M. Rakoczy, Warszawa 2010.

${ }^{30}$ L. Febvre, H.-J. Martin, Narodziny książki, tłum. A. Kocot, M. Wodzyńska-Walicka, Warszawa 2014.

31 P. Rodak, Pismo, ksiażka, lektura. Rozmowy: Le Goff, Chartier, Hébrard, Fabre, Lejeune, Warszawa 2009.

32 J. Sowiński, Sztuka typograficzna Młodej Polski, Wrocław 1982; idem, Adam Półtawski. Typograf artysta, Wrocław 1988; idem, Typografia wytworna w Polsce 1919-1939, Wrocław 1995; idem, Polskie drukarstwo. Historia drukowania typograficznego i sztuki typograficznej w Polsce w latach 1473-1939, Wrocław 1996; idem, Czy Johann Gutenberg był pierwszym detepowcem, [w:] Sztuka książki. Historia - teoria - praktyka, pod red. M. Komzy, Wrocław 2003, s. 229-233.

33 Z. Staniszewski, Estetyka polskiego druku książkowego XVIII w. Zarys problematyki, „Ze Skarbca Kultury" 1950, z. 1 (12), s. 120-164.

${ }_{34}$ Zob. odpowiednie eseje i hasła: Encyklopedia książki, pod red. A. Żbikowskiej-Migoń i M. Skalskiej-Zlat, Wrocław 2017.

35 Autorka niniejszego tekstu starała się odpowiedzieć na to pytanie w artykule Bibliolog na rozdrożu. Jak można dzisiaj badać stare druki?, „Wielogłos” 2012, nr 3 (13), s. 199-210. 
sza, który odszedł od dużych, nieporęcznych formatów ksiąg (folio) i rozpoczął produkcję książek przenośnych (zwanych libri portabiles), które zmniejszały się, dochodząc do formatu octavo ${ }^{36}$.

\section{PERSPEKTYWY BADAŃ NAD DAWNĄ KSIĄŻKĄ I ICH PRAKTYCZNE ZASTOSOWANIE}

Od najdawniejszych czasów książka zawdzięczała swą formę kilku czynnikom: technologii wykonania, materiałom, przyzwyczajeniu czytelniczemu i szerzej pojętej ergonomii, ekonomii wykonania oraz indywidualizmowi twórcy, kopisty, iluminatora, zecera, rytownika itp. Dlatego badanie formy książki nie może się zatrzymać wyłącznie na jednym z tych aspektów. Badacz powinien uwzględnić wpływ wszystkich tych czynników na projekt typograficzny. Co więcej, oddziałują one na siebie nawzajem, sprawiając, że niektóre rozwiązania typograficzne pojawiają się z wyraźną regularnością. Przykładem może być np. związek między formatami papieru, wynikającymi z możliwości technicznych papierników, a formatami książek, będącymi najczęściej wariacjami na temat sposobu ich złożenia. Ponieważ papier był bardzo drogi, oszczędnie nim gospodarowano. Dbałość o jego dobre wykorzystanie widoczna jest wyraźnie w dawnych podręcznikach drukarstwa, które pokazują różne sposoby rozłożenia stronic na arkuszu drukarskim (impozycji). Już pierwszy podręcznik drukarstwa autorstwa Josepha Moxona Mechanick Exercises on the Whole Art of Printing wydany w Londynie (1683) zawierał trzy ilustracje pokazujące rozłożenie stron na arkuszu (ryc. 26-28). Podobny, choć dużo obszerniejszy, materiał zawierają prace późniejsze: niemiecki podręcznik Christiana Friedricha Gessnera In der Buchdruckerey wohl unterrichtete Lehrjungen, oder Anfangsgründe der Buchdruckerkunst (Lipsk 1743) poświęca temu zagadnieniu ponad sto stron (s. 2-110). Temat jest obecny także we francuskim opracowaniu Martina Dominique'a Fertela La Science pratique de l'imprimerie (Saint Omer 1723, s. 142-178). Staranny układ stronic na arkuszu pozwalał bardziej ekonomicznie wykorzystać zasób papieru, ale zmuszał również zecera do dokładnego zaplanowania projektu, tak aby zmieścił się na konkretnej liczbie arkuszy.

To praktyczne rozwiązanie ma jednak dodatkowy aspekt związany z estetyką. Dokładny pomiar i analiza wykorzystywanych formatów wskazują, że przybierały one klasyczne proporcje, zgodne z przekonaniami estetycznymi epoki. I tak np. już najwcześniejsze „standardowe” formaty w Europie, czyli te wykute na marmurowym słupie w Bolonii w końcu wieku XIV ${ }^{37}$, miały bardzo określone

36 J. Gruchała, op. cit., s. 203-204; K. Houston, Książka. Najpotężniejszy przedmiot naszych czasów zbadany od deski do deski, tłum. P. Lipszyc, Kraków 2017, s. 356-357.

37 Zob. K. Houston, op. cit., s. 362. 
proporcje: dwa z nich, imperialle o wymiarach $740 \times 500^{38}$ (stosunek wysokości do szerokości 1:1,48) i mecome $515 \times 345$ (1:1,49), to niemal idealna kwinta czysta (proporcja 2:3, 1:1,5); format realle $615 \times 445(1: 1,38)$ to proporcja tzw. niskiego pięciokąta $(1: 1,376)$, a najmniejszy recute $450 \times 315(1: 1,42)$ zbliża się do współczesnej normy ISO, wynoszącej 1: $\sqrt{2}$, czyli 1:1,414. Późniejsze źródła wskazują ${ }^{39}$, że w niektórych krajach europejskich (Anglia, Francja, Holandia i Niemcy) złożone arkusze papieru najczęściej przybierały proporcje wysokiego pięciokąta $\left(1: 1,701^{40}\right)$, seksty wielkiej $\left(1: 1,667^{41}\right)$, złotego podziału $\left(1: 1,618^{42}\right)$, seksty małej $\left(1: 1,6^{43}\right)$, pięciokąta $\left(1: 1,539^{44}\right)$ i kwinty czystej ${ }^{45}$. W XVIII wieku produkowano papier w ponad 60 formatach. Według ustaleń Staniszewskiego najpopularniejszymi z nich były: propatria $(340 \times 430$ i $360 \times 460)$, jednorożec $(400 \times 500$ i $420 \times 530)$, median $(440 \times 560$ i $460 \times 590)$, royal $(480 \times 640$ i $540 \times 680)$, lexicon $(500 \times 650)$, imperial $(570 \times 780)$ i inne ${ }^{46}$. Wszystkie z nich odpowiadają proporcjom uznawanym przez wieki za klasyczne: propatria $(1: 1,264$ i 1:1,277), jednorożec $(1: 1,25$ i 1:1,26), median $(1: 1,2727$ i 1:1,2828) i większy format royal $(1: 1,25)$ mają wymiary o proporcjach zbliżonych do tercji wielkiej, natomiast mniejszy royal $(1: 1,333)$, lexicon $(1: 1,3)$ oraz imperial $(1: 1,36)$ reprezentują kwartę czystą. Co więcej, złożenie takiego papieru, praktykowane w drukarniach, pozwalało uzyskać formaty będące wynikiem specjalnej własności proporcji muzycznych, a mianowicie ich komplementarnego dopełniania się na zasadzie tzw. przewrotów interwałów. Dlatego średniowiecze preferowało format arkusza o proporcjach kwarty czystej, gdyż jej złożenie daje kwintę czystą, także uważaną za wyjątkowo estetyczną.

Takie podejście do materiałów drukarskich nie wyklucza oczywiście badań nad pochodzeniem wykorzystywanego w drukach papieru, dlatego przydatne

38 Wszystkie wielkości podane w milimetrach.

39 Zob. format papieru, [hasło w:] Encyklopedia wiedzy o ksiązce, Wrocław 1971, kol. 724725.

40 Holenderski olifants $(720 \times 620,1: 1,72)$.

${ }^{41}$ Holenderskie royaal $(620 \times 520,1: 1,67)$, gr. median $(560 \times 470,1: 1,68)$.

42 Holenderskie $k l$. median $(540 \times 440,1: 1,62)$, schrijfformaat $(420 \times 340,1: 1,61)$.

43 Angielskie royal $(600 \times 480,1: 1,6)$, medium $(576 \times 456,1: 1,58$ oraz $528 \times 432,1: 1,565)$, large post $(504 \times 396,1: 1,57)$, demy, writing $(380 \times 372,1: 1,56)$; francuskie couronne $(720 \times 460$, plano 1:1,565), carré $(560 \times 450,1: 1,6)$, coquille $(560 \times 440,1: 1,56)$; niemieckie Super Royal $(680 \times 540,1: 1,58)$, Kl. Median $(560 \times 440,1: 1,57)$, Register $(530 \times 420,1: 1,58)$, Bischof $(480 \times 380$, 1:1,58), Bienenkorb $(450 \times 360,1: 1,6)$, Pro patria $(430 \times 340,1: 1,58)$.

44 Angielskie demy, printing $(520 \times 420,1: 1,55)$; francuskie raisin $(650 \times 500,1: 1,53)$, tellière $(440 \times 340,1: 1,54)$; holenderskie folio post $(565 \times 435,1: 1,53), k l$. post $(480 \times 570,1: 1,54)$; niemiecki Lexicon $(650 \times 5001: 1,54)$.

45 Francuskie royal $(630 \times 480,1: 1,52)$; niemiecki Regal z 1501 roku $(670 \times 440,1: 1,52$ plano $)$.

46 Z. Staniszewski, op. cit., s. 128-129. 
są nadal w badaniach nad dawną książką klasyczne opracowania Włodzimierza Budki i Jadwigi Siniarskiej-Czaplickiej ${ }^{47}$.

Decyzje drukarza często były dyktowane czynnikami w pewnym sensie obiektywnymi: zwykle wybór kroju pisma musiał się zawęzić do zasobu kaszty. Jednak wydaje się, że drukarze dawni przywiązywali dużą wagę do wyboru kroju pisma. To jeden z najważniejszych elementów projektu, wpływający na czytelność. Prócz tego właściciele niektórych oficyn wyraźnie dążyli do pozyskiwania nowych, modnych pism, widząc w tym reklamę dla swojego warsztatu. Badania nad pismem dawnym to dziedzina wymagająca żmudnej pracy porównawczej. Przede wszystkim analiza pism drukarskich wymaga sięgnięcia po terminologię i metody pracy historyków pisma. Na gruncie polskim specjalistką w tym zakresie jest Maria Juda. W swojej monografii Pismo drukowane w Polsce XV-XVIII wie$k u^{48}$ przywołała metodologię badań typograficznych, poczynając od Georga Wolfganga Panzera, Henry'ego Bradshawa, Roberta Proctora i Konrada Haeblera ${ }^{49}$, a na polskich bibliologach kończąc. Autorka, opisując budowę poszczególnych liter, zastosowała metody i terminologię zaproponowane przez Alfreda Hesse$1 \mathrm{l}^{50}$, a później podjęte przez badaczy pism gotyckich i postgotyckich, m.in. Ernesta Crousa, Joachima Kirchnera, Carla Wehmera, Stanleya Morisona i Alfreda F. Johnsona ${ }^{51}$. W kręgu tym znaleźli się również polscy badacze, wybitni autorzy dzieł z zakresu paleografii: Władysław Semkowicz, Aleksander Gieysztor oraz Janusz Słowiński ${ }^{52}$. Opisywanie i analiza pism drukarskich wymagają również wiedzy o technologii druku. Nieocenioną pomocą w tym względzie jest cykl artykułów Romana Tomaszewskiego ukazujący się w czasopiśmie „Litera”,53, obejmujący przede wszystkim terminologię związaną ze stopniami pisma, a także

47 W. Budka, Znaki wodne papierni w Rzeczypospolitej Polskiej XVI w., [w:] Papiernie w Polsce XVI wieku, Wrocław 1971; J. Siniarska-Czaplicka, Filigrany papierni położonych na obszarze Rzeczypospolitej Polskiej od poczatku XVI do połowy XVIII w., Wrocław 1969; eadem, Katalog filigranów czerpalni Rzeczypospolitej zebranych z papieru druków tłoczonych w latach 1500-1800, Łódź 1983.

48 M. Juda, Pismo drukowane w Polsce XV-XVIII wieku, Lublin 2001.

49 Przywołując przede wszystkim metodę badania najwcześniejszych druków uwzględniającą prócz kształtu znaków także wysokość czcionek, upowszechnioną gównie przez Haeblera (zob. idem, Typenrepertorium der Wiegendrucke, cz. 1-5, Halle a. S.-Leipzig 1905-1924).

50 A. Hessel, Von der Schrift zum Druck, ,Zeitschrift des Deutschen Vereins für Buchwesen und Schrifttum" 1923, nr 3/4, s. 83-92.

51 E. Crous, J. Kirchner, Die gotischen Schriftarten, wyd. 2, Braunschweig [1970]; C. Wehmer, Die Namen der gotischen Buchschriften. Beitrag zur Geschichteder latenischen Paläographie, „Zentralblatt für Buchwesen” 49, 1932, s. 11-34, 169-176, 222-234; S. Morison, Meisterdrucke gotischer Schrift. Deutsche Inkunabeln im Britischen Museum, Berlin 1928; A.F. Johnson, The classification of gothic types, „The Transactions of the Bibliographical Society” 9, 1929, nr 4, s. 357-380.

52 W. Semkowicz, Pojęcie i zakres paleografii, „Litera” 1967, nr 10, s. 146-150; idem, Paleografia łacińska, Kraków 2011; A. Gieysztor, op. cit.; J. Słowiński, Rozwój pisma łacińskiego w Polsce XVI-XVIII wieku. Studium paleograficzne, Lublin 1992.

53 R. Tomaszewski, Dziewięć wieków czcionkarstwa, cz. 2, „Litera” 1971, nr 1, s. 17-24. 
dzieła Harry'ego Cartera (omawiające problematykę wczesnego okresu rozwoju druku), Petera Burnhilla (o wewnętrznych normach typograficznych stosowanych przez Manucjusza) oraz Richarda Southalla (dostosowywanie projektu pisma do zmieniających się w XX wieku technologii druku) ${ }^{54}$. Niewielkim, w porównaniu $\mathrm{z}$ innymi sprawami, problemem staje się terminologia stosowana $\mathrm{w}$ analizie kroju pisma. Niekiedy pojawiają się równolegle terminy oznaczające te same elementy liter, a pochodzące z dwóch różnych kręgów badaczy: jeden bliższy jest liternictwu i typografii ${ }^{55}$, drugi zaś kaligrafii i paleografii. Te dwa bieguny są jednak płynnie łączone w opracowaniach Gerrita Noordzija ${ }^{56}$, co wskazuje, że nie ma między nimi konfliktu metodologicznego.

Pismo stanowi także jeden z głównych środków wyrazu w typografii, dlatego dla badacza niezwykle istotne stają się kanoniczne prace słynnych typografów i historyków książki: Jana Tschicholda ${ }^{57}$, Roberta Bringhursta ${ }^{58}$, opracowania Daniela B. Updike’a, Tibora Szántó, Frederica W. Goudy’ego, Alexandra Lawsona, Fransa A. Janssena ${ }^{59}$ i innych. Równie wartościowe okazują się publikacje omawiające proces projektowania pisma, gdyż najczęściej wprowadzają także kontekst historyczny, niezbędny do prawidłowego zrozumienia kształtu poszczególnych znaków, oraz ujęcie funkcjonalne, związane z badaniami nad czytelnością. Warto w tym miejscu przywołać nazwiska specjalistów w tym zakresie: Gerarda Ungera, Karen Cheng i Waltera Tracy'ego ${ }^{60}$. W Polsce ukazał się również podręcznik trojga autorów José Scaglionego, Laury Meseguer, Cristóbala Henestrosy pt. Jak

${ }^{54}$ H. Carter, op. cit.; P. Burnhill, Type Spaces In-House Norms in the Typography of Aldus Manutius, London 2003; R. Southall, Printer's Type in the Twentieth Century. Manufacturing and Design Methods, London 2005.

55 A. Tomaszewski, Pismo dziełowe, cz. 1, „Wydawca” 1998, nr 3, s. 19-20; cz. 2, „Wydawca” 1998, nr 9, s. 34-35, 39; J. Benedyktowicz, Minuskuła, „Litera” 1967, nr 1, s. 2-5; idem, Medytacje o projektowaniu minuskułowej czcionki dziełowej, „Litera” 1967, nr 7, s. 106-109; H. Zapf, Problemy projektowania pism dziełowych, „Litera” 1968, nr 3, s. 41-43; nr 5, s. 78-80; nr 6, s. 94-96; J. Tschichold, Znaczenie tradycji w projektowaniu nowych pism drukarskich, „Litera” 1969, nr 1, s. 1-4; A. Kapr, Anatomia liter tacińskich, cz. 1, „Litera” 1972, nr 1, s. 28-32; dokończenie, „Litera” 1972, nr 2, s. 35-54; R. Rożek, Czytelność pism historycznych, „Litera” 1973, nr 3, s. 96-108; R. Tomaszewski, Percepcja znaków a projektowanie pism drukarskich, „Litera” 1973, nr 1, s. 3-23.

56 G. Noordzij, Kreska. Teoria pisma, tłum. M. Komorowska, Kraków 2014.

57 J. Tschichold, Treasury of Alphabets and Lettering, London 1966; idem, Znaczenie tradycji w projektowaniu nowych pism drukarskich, „Litera” 1969, nr 1, s. 1-4.

58 R. Bringhurst, Elementarz stylu w typografii, tłum. D. Dziewońska, Kraków 2007.

59 D.B. Updike, Printing Types, Harvard 1951; T. Szántó, Pismo i styl, Wrocław 1986; F.W. Goudy, Typologia. Studies in Type Design \& Type Making with Comments on the Invention of Typography. The First Types Legibility and Fine Printing, Berkeley 1940; A. Lawson, Anatomy of a Typeface, Boston 2010; F.A. Janssen, Technique and Design in the History of Printing, Houten 2004.

60 G. Unger, While You're Reading, New York 2007; K. Cheng, Designing Type, London 2005; W. Tracy, Letters of Credit. A View of Type Design, London 1986. 
projektować kroje pisma. Od szkicu do ekranu ${ }^{61}$. Zainteresowanie rozwojem i rolą pisma w typografii nie słabnie, o czym świadczą najnowsze publikacje ukazujące się również w języku polskim, jak chociażby powstała w 2010 roku praca Hendrika Webera o kursywie ${ }^{62}$. Warto też dodać, że na obrzeżach zainteresowań typograficznych powinny się również znaleźć prace specjalistyczne związane z rozwojem języka i systemu zapisu, bardzo istotnym ze względu na zmiany w sposobie składu, dlatego do listy przydatnych w tym temacie autorów należy dodać Zenona Klemensiewicza i Andrzeja Padzińskiego ${ }^{63}$.

Trudno podważać wartość badań nad dawnym pismem, jednak takie studia nie muszą mieć wyłącznie znaczenia dokumentacyjnego. Mogą również przydawać się współczesnym projektantom, zarówno pism, jak i publikacji. Przede wszystkim wiedza o dawnej technologii pozwala zrozumieć rozwiązania projektowe, na jakie zdecydowali się dawni giserzy. Od chwili, gdy Gutenberg wynalazł ruchomą czcionkę, aż do II połowy wieku XX proces druku wypukłego przebiegał podobnie. Przygotowanie czcionki wymagało kilku etapów pracy ${ }^{64}$. Pierwszym z nich było sporządzenie patryc, punconów (ponsonów, jak je nazywają niektóre źródła ${ }^{65}$ ) polegające na mozolnej obróbce sztabki twardego metalu, wybijanie w nim podstawowych kształtów i żłobienie dokładnego wizerunku litery. Za pomocą patrycy wybijano w miedzi matrycę, z której później odlewano czcionki. W muzeach europejskich zachowały się oryginalne materiały pochodzące z drukarń Plantina ${ }^{66}$, Caslona ${ }^{67}$

61 J. Scaglione, L. Meseguer, C. Henestrosa, Jak projektować kroje pisma. Od szkicu do ekranu, Kraków 2013.

62 H. Weber, Kursywa. Wyróżnienie w typografii, tłum. P. Piszczatowski, Kraków 2017.

63 Z. Klemensiewicz, Historia języka polskiego, Warszawa 1985; A. Padziński, Brachygrafia w epigrafice i typografii polskiej XVI-XVIII, „Folia Bibliologica” 34/35, 1986/1987, s. 7-18.

64 Dokładny opis procesu podaje F. Smeijers w cytowanej publikacji oraz A. Tomaszewski, Giserzy czcionek w Polsce, Warszawa 2009, s. 5-16.

65 Tak w inwentarzach i wzornikach, np. w druku zawierającym wzory pism drukarni krakowskiego Seminarium Biskupio-Akademickiego pt. Specimen characterum sive typorum typographiae seminarii episcopalis academico-dioecesani Cracoviensis z roku 1783.

66 Zob. Hendrik van den Keer (1540-1580). Grande musicque, Museum Plantin-Moretus [serwis internetowy], http://www.museumplantinmoretus.be/nl/pagina/hendrik-van-den-keer1540-1580-grande-musicque [dostęp: 30.10.2017].

67 Ostatnie badania dowodzą, że matryce przechowywane w zbiorach St. Bride Foundation w Londynie zostały najprawdopodobniej wykonane w XIX wieku. Jednak dla celów reklamowych zostały nazwane oryginalnymi w wydanym w 1896 wzorniku pt. Specimens of the original Caslon Old Face printing types, engraved in the early part of the 18th century by Caslon I - zob. Recasting Caslon Old Face, Typefoundry [blog], 4.01.2009, http://typefoundry.blogspot.com/2009/01/ recasting-caslon-old-face.html?m=1 [dostęp: 3.11.2017]. Więcej na temat zbiorów: The Treasure of St. Bride: Part I, „Type. A magazine for people curious about font”, 13.10.2017, https://www. typemag.org/home/2017/10/13/the-treasure-of-st-bride-part-i, oraz The Treasure of St. Bride Part II, 28.10.2017, https://www.typemag.org/home/2017/10/28/the-treasure-of-st-bride-part-ii [dostęp: 15.11.2017]. Matryce tego kroju trafiły też za ocean, do Ameryki Północnej (A. Lawson, op. cit., s. 175). Istnieją spekulacje, że mogły to być oryginalne matryce XVIII-wieczne.

Roczniki Biblioteczne 61, 2017

(C) for this edition by CNS 
i Bodoniego ${ }^{68}$, znamy także opisy tego procesu obecne w podręcznikach drukarstwa oraz w Wielkiej Encyklopedii Francuskiej. Warto jednak zdać sobie sprawę, że te świadectwa historyczne pomagają współczesnym projektantom zrozumieć podstawowe założenia twórców krojów sprzed wieków. Przede wszystkim sam proces druku polegający na tłoczeniu w dość miękkim i podatnym materiale, jakim był papier czerpany, twardymi metalowymi czcionkami sprawiał, że mazista farba ulegała rozgnieceniu i powiększała znacznie obrys litery. Drukarze, a nade wszystko giserzy wiedzieli także, że drobne oczka liter mogą ulegać „zabijaniu”, czyli zaklejaniu farbą wąskich elementów, czemu zapobiegało podcinanie linii litery tak, by powstały tzw. pułapki farbowe niwelujące te zniekształcenia ${ }^{69}$. Wydawać by się mogło, że to interesujące, choć dziś już całkiem nieprzydatne informacje, stanowiące raczej ciekawostkę historyczną. O tym, że jest zupełnie inaczej, przekonali się jednak projektanci próbujący dokonać adaptacji cyfrowej ${ }^{70}$ kroju, który powstał w technice druku wypukłego w XVIII wieku w słynnej oficynie Caslonów ${ }^{71}$. Problemy, na jakie się natknęli, były, jak się okazało, bardzo typowe dla większości prób digitalizacji krojów dawnych. W przypadku krojów Caslona korzystano głównie z wzorników oraz innych druków, czyniąc z nich podstawę przyszłego pisma cyfrowego. Okazało się jednak, że skutki były co najmniej niezadowalające: współczesny druk offsetowy i cyfrowy reprodukuje litery w zupełnie inny sposób. W offsecie stosuje się płaską formę drukową; jest to druk pośredni, a więc obraz znaku przechodzi z płyty na gumę pokrywającą drugi cylinder maszyny, a z niej dopiero na papier, co powoduje brak silnego docisku obecnego w druku wypukłym. W tej technice używa się też innego typu papierów i farb. Z kolei różne rodzaje druku cyfrowego w ogóle nie wymagają formy druko-

68 Zob. Museo Bodoniano [serwis internetowy], http://www.museobodoni.beniculturali.it/ index.php?it/120/collezioni [dostęp: 30.10.2017].

69 W taki sposób Matthew Carter zaprojektował w latach 1975-1978 Bell Centennial, krój przeznaczony do druku książek telefonicznych. Pułapki farbowe miały poprawić jakość druku małym stopniem pisma na papierze niższej jakości — zob. R. Reuß, Perfekcyjna maszyna do czytania. O ergonomii książki, Kraków 2017, s. 70-71; Matthew Carter Bell Centennial 1976-1978, Museum of Modern Art [serwis internetowy], 2011, https://www.moma.org/collection/works/139307 [dostęp: 10.11.2017].

70 Termin „adaptacja” jest szerszy niż „digitalizacja” i oznacza według Andrzeja Tomaszewskiego „graficzną przeróbkę dawnego kroju pisma, polegającą na jego przystosowaniu do wymagań nowej technologii składania lub produkcji nośnika pisma, wyświetlania pisma na ekranie tv itp., dokonaną z zachowaniem oryginalnych cech formalnych kroju" - idem, Leksykon pism drukarskich, Warszawa 1996, s. 14.

71 Prace nad adaptacjami cyfrowymi tego kroju opisał William Berkson, twórca czterech odmian pisma o nazwie Williams Caslon Text - zob. idem, Reviving Caslon. Part 1. I Love Typography, I love typography [portal] 26.07.2010, http://ilovetypography.com/2010/07/26/revivingcaslon-the-snare-of-authenticity/ [dostęp: 3.11.2017], oraz Part 2. I Love Typography, 2.11.2010, http://ilovetypography.com/2010/11/02/reviving-caslon-part-2-readability-affability-authority/ [dostęp: 5.11.2017]. 
wej i nacisku. Zadowalająca adaptacja nie może być więc repliką, lecz musi zostać dostosowana do innej technologii i zmieniona zgodnie z zasadami czytelności.

Zróżnicowanie technik drukarskich tłumaczy nieco fakt, że te same klasyczne kroje występują w bardzo wielu wariantach — były bowiem adaptowane wielokrotnie do różnych typów nośników ${ }^{72}$. Drugim zagadnieniem związanym z problemem digitalizacji był brak świadomości funkcjonowania niemal od początku druku tzw. odmian optycznych. Dawni giserzy wiedzieli bardzo dobrze, że litery danego kroju odlewane w metalu w konkretnych wielkościach muszą zostać zaprojektowane inaczej, nie tylko ze względu na odkształcenia powstające $\mathrm{w}$ procesie odbijania ich na papierze, ale również z powodu różnego sposobu postrzegania ich przez ludzkie oko. Bardzo małe stopnie pisma odlewano już w XVI wieku - jako pierwszy wyciął pismo sześciopunktowe (Nonpareille Romaine) Pierre Haultin. Było ono używane w oficynie Plantina od roku $1557^{73}$. Już wówczas projektowano kroje w kilku wariantach optycznych. Tę zależność dostrzegają również współcześni projektanci Cristóbal Henestrosa, Laura Meseguer, José Scaglione, którzy we wspomnianym już podręczniku Jak projektować kroje pisma podają, że także dzisiaj wyróżnia się cztery odmiany optyczne dla różnych stopni pisma: dla wielkości rzędu 6-8 pkt (notkowa), 9-14 (tekstowa), 14-24 (śródtytułowa) i ponad 24 pkt (tytułowa) ${ }^{74}$. W taki sposób projektuje się niektóre współczesne kroje. Doskonałymi przykładami takich eksperckich fontów są Arno Pro Roberta Slimbacha czy Neakademia oferowana przez dom typograficzny Rosetta. Ciekawe, że praktykę projektowania zgodnego z tymi zasadami dostrzec można już w stosunkowo wczesnych drukach reklamujących zasoby oficyn drukarskich (jak we wzorniku wydanym w roku 1592, pochodzącym z oficyny Egenolffa Bernera, czy w kolejnych wzornikach Caslonów). Stopnie większe były projektowane jako wyższe, o nieco wydłużonym kształcie, cieńszej i bardziej skontrastowanej kresce oraz ciaśniejszych odstępach międzywyrazowych (mniejsze odsadki); stopnie średnie, najbardziej typowe, o dość regularnych proporcjach i uśrednionych wydłużeniach górnych i dolnych; najmniejsze zaś — notkowe miały bardziej zaokrąglone kształty, większe światła wewnętrzne (punce) i międzyznakowe, bardziej zrównoważony kontrast i silniejszy kolor. Duże stopnie pozwalały giserom wzbogacić kształt litery o dodatkowe, charakterystyczne elementy (dekoracyjne dzioby, wyraźne szeryfy i ozdobniki); mniejsze stopnie, zwłaszcza w odmianach notkowych, były ich, z oczywistych względów, pozbawione.

W próbach digitalizacji popełniano podstawowy błąd, wybierając nieodpowiedni wzór do przeniesienia go w środowisko cyfrowe. Podstawą digitalizacji

72 P. Shaw, Revival Type. Digital Typefaces Inspired by the Past, London 2017; A. Tomaszewski, Historyczne kroje pism a fonty komputerowe, „Roczniki Biblioteczne” 46, 2002, s. 255-266.

73 Tak małe stopnie pisma mogły być potrzebne do druku protestanckich kieszonkowych Biblii, stąd próby ich wykonania - zob. F. Smeijers, op. cit., s. 68.

74 J. Scaglione, L. Meseguer, C. Henestrosa, op. cit., s. 102. 
stawało się najczęściej pismo zachowane w największym stopniu, jako że dawało duże możliwości wiernego i dokładnego odtworzenia szczegółów. Współczesne metody pozwalają je bardzo pieczołowicie uwzględnić w wersji cyfrowej, co staje się niestety przyczyną klęski takiego podejścia, gdyż wzory przeznaczone do stopni większych przeniesione do rozmiarów pisma notkowego, zarówno przez nieprawidłowe proporcje, jak i poprzez nadmiar szczegółów, znacznie tracą na czytelności. Prócz tego mechaniczne zmniejszenie sprawia, że linie stają się za cienkie, co również obniża czytelność i sprawia, że litery w druku wydają się zbyt jasne. Dopiero rzetelna wiedza oparta na badaniach historycznych pozwala współczesnym projektantom podjąć właściwe decyzje o wyborze podstawy adaptacji. Porównanie dwóch digitalizacji kroju Caslona wskazuje, jak ważna jest to decyzja. Carol Twombly, autorka fontu Adobe Caslon, wybrała jako wzór małe stopnie pisma: English Roman no. 2, Pica Roman nos. 1 i 2, Small Pica Roman no. 2, Long Primer Roman no. 1 oraz Brevier Roman no. 2, natomiast Matthew Carter przy pracach nad krojem Big Caslon oparł się na wzorach największych stopni: Five Lines Pica i Four Lines Pica. Dlatego też krój Adobe sprawdza się znacznie lepiej jako pismo tekstowe, a Big Caslon wygląda doskonale w tytułach ${ }^{75}$.

To oczywiście nie są wszystkie problemy związane z tym tematem. Liczne próby digitalizacji wskazują, że projektanci obierają bardzo różne drogi do tego samego (przynajmniej pozornie) celu. Niektórzy decydują się na konkretny wzór, np. z matrycy lub z druków (czasem nawet z niedoskonałościami, oddającymi „koloryt” dawnego procesu drukarskiego ${ }^{76}$ ), inni uznają, że krój historyczny jest tylko punktem wyjścia dla nowego pisma, przeprojektowanego i w pełni dostosowanego do nowego typu nośnika. Przykładem takich działań jest wspomniana już adaptacja Caslona, a w Polsce digitalizacja kroju Bona Andrzeja Heidricha wykonana przez Mateusza Machalskiego ${ }^{77}$. Obydwa te kroje zostały przeprojektowane, a podstawą stały się pisma w oryginale przeznaczone do składu ręcznego. W przypadku Bony wykorzystano też rysunki autora. Proces dostosowania objął liczne zmiany w kształcie liter oraz dodanie do tego kroju, występującego w oryginale wyłącznie jako kursywa, także odmiany prostej i półgrubej. Dzięki takiemu podejściu dawna czcionka, która nie bardzo miała szansę zaistnieć, gdyż została odlana w momencie, gdy era składu ręcznego praktycznie odchodziła już do historii, może służyć projektantom w nowym środowisku, jakim są nowoczesne techniki druku oraz przestrzeń Internetu.

Badania nad pismem mogą być pomocne nie tylko projektantom krojów, ale również innym twórcom, np. grafikom. Każdy z nich staje zwykle przed dylema-

75 P. Shaw, op. cit., s. 80.

76 Taką decyzję podjął Justin Howes, adaptując w latach 90. XX wieku krój Williama Caslona z roku 1734 nazwany ITC Founder's Caslon Twelve.

77 Oryginalny krój został zaprojektowany w roku 1971 - zob. Bona Nova, oprac. M. Machalski, https://asp.waw.pl/wp-content/uploads/2017/06/Bona_Nova_PRESS_MASTER.pdf [dostęp: 2.11.2017]. 
tem, jaki krój pisma wybrać do swojego projektu. Wybór ten, wobec ogromnej mnogości pism dostępnych współcześnie, jest niebagatelny. Oczywiście głównym kryterium powinna być czytelność, jednak nawet podstawowa znajomość cech pisma, klasyfikujących je do konkretnych grup, pozwala podjąć trafniejszą decyzję. Kolejnym problemem jest kontrastowanie pism, kroje można bowiem zestawiać według różnych kryteriów. Najbardziej przekonujące są zestawienia oparte o pewną zbieżność pism, np. pochodzących z jednej rodziny lub o podobnej budowie. Można również połączyć z sobą kroje skrajnie kontrastowe, o takich cechach strukturalnych, które podkreślają ich inność. Ostatni sposób zestawienia krojów bazuje na ich pochodzeniu historycznym i zaleca dobór pism z tego samego okresu. Stworzenie komplementarnej pary wymaga wiedzy o historii i budowie pisma.

W tym kontekście widać, że analiza kształtu typograficznego książki dawnej przestaje być wyłącznie przedmiotem badań archiwalnych i teoretycznych i staje się źródłem wiedzy i inspiracji dla współczesnych projektantów. Potwierdzają to coraz liczniej ukazujące się na Zachodzie i tłumaczone także na język polski publikacje dotyczące teorii i praktyki projektowania w kontekście książki dawnej. Co więcej, rozwój nowych mediów może być pretekstem do zastanowienia się nad znaczeniem pięćsetletniej tradycji typograficznej ${ }^{78}$. Dlatego takie zagadnienia, jak forma i funkcja starodruku, technologia typograficzna i jej wpływ na projekt, rozwój typografii w dziejach itp., stają się tematami równie istotnymi dla projektanta, jak teoria komunikacji, badania nad czytelnością lub rozwój nowych mediów ${ }^{79}$. Badacze coraz częściej porównują moment wynalezienia przez Gutenberga ruchomej czcionki i rozpoczęcia nowej epoki druku, całkowicie rewolucjonizującej ówczesne społeczeństwo, do sytuacji obecnej — przeniesienia procesu komunikacji w środowisko cyfrowe. Niektórzy z nich, jak np. Michael Giesecke, postulują zmianę perspektywy badawczej z bibliologicznej na teorię informacji, gdyż tylko w takim ujęciu można wynalazek Gutenberga uznać za punkt zwrotny w historii kultury ${ }^{80}$.

Dla dizajnerów badania nad książką dawną, ukazujące ewolucję poszczególnych środków wyrazu, mogą być niezwykle inspirujące, czego dowodem są liczne stylizacje obecne w projektach. Takie podejście nie jest niczym nowym: już William Morris, świadomie sięgając po dawne rozwiązania liternicze i pro-

${ }^{78}$ H. Hoeks, E. Lentjes, Przedmowa, [w:] Triumf typografii. Kultura. Komunikacja. Nowe media, wybór i oprac. idem, tłum. M. Komorowska, Kraków 2017, s. 11.

${ }^{79}$ Zob. W. Frijhoff, Rewolucja druku, [w:] Triumf typografii..., s. 36-57; R. de Jong, Aventur, czyli awantura, a czasami również sztuka. Europejska typografia od czasu Gutenberga, [w:] Triumf typografii..., s. 58-79; P. Dijstelberge, Mariaż technologii z tradycja — projektowanie w dobie druku na prasie ręcznej (1460-1830), [w:] Triumf typografii..., s. 80-93; P. van Capelleveen, Typograficzne odrodzenie XIX stulecia (1801-1915), [w:] Triumf typografii.., s. 94-107; Ch. Gassner, Nowa typografia. Od secesji do końca druku wypuktego, [w:] Triumf typografii..., s. 108-121.

${ }^{80}$ M. Giesecke, Od systemu skryptograficznego do typograficznego. Kultura książki jako społeczeństwo informacyjne, [w:] Triumf typografii..., s. 168-181. 
jektowe, stworzył nową jakość książki. Inny wielki projektant czerpiący z historii, Jan Tschichold, był także miłośnikiem kaligrafii. Pasję badacza dawnej książki z praktyką projektową łączyli również Albert Kapr i Adrian Frutiger. Na polskim gruncie doskonałym przykładem takiego podejścia był Leon Urbański ${ }^{81}$, a obecnie także Andrzej Tomaszewski ${ }^{82}$. To właśnie on stara się od lat krzewić w Polsce ideę projektu kongenialnego, od dawna obecną za granicą. Taki typ projektu skłania projektanta do troski o płynne połączenie treści, formy i funkcji $\mathrm{książki}^{83}$. Ponieważ forma jest determinowana przez funkcję i treść, dobór środków powinien również uwzględniać aspekty historyczne. Nie znaczy to oczywiście, że projektant powinien dzieło Reja złożyć szwabachą w tradycyjnej ramce drzeworytowej. Stylizacja może być dużo bardziej finezyjna, np. zakładać format i proporcje charakterystyczne dla danej epoki, stanowić dialog poprzez dobrze skontrastowane historyczne kroje pism lub zastosowanie takich rozwiązań, jak marginalia.

Warto jeszcze wspomnieć o szczególnym środku wyrazu, występującym w książce wraz z tekstem, a mianowicie o ilustracji. Istnieją publikacje, w których stanowi ona - nomem omen - objaśnienie lub uzupełnienie tekstu, są jednak i takie, w których jest równoważna $z$ tekstem. Prześledzenie narodzin ilustracji i jej ewolucji w książce dawnej pozwala zrozumieć jej funkcjonowanie także w projekcie współczesnym. Do analizy materiału graficznego niezbędne stają się opracowania z zakresu historii sztuki ${ }^{84}$. W badaniach nad grafiką dawną sprawdza się dobrze m.in. metoda ikonologiczna rozwinięta przez Erwina Panofsky'ego, a w Polsce popularyzowana przez Jana Białostockiego ${ }^{85}$. Jej humanistyczne korzenie stają się szczególnie istotne w okresach historycznych, w których drukarze chętnie łączyli tekst z obrazem. Drugim nurtem badań nad sztuką, który pomaga lepiej zrozumieć znaczenie grafiki w publikacji, jest psychologia percepcji, obecna szczególnie w klasycznych opracowaniach Ernsta H. Gombricha i Rudolfa Arnheima ${ }^{86}$. W pracach badawczych nad książką dawną przydatne są także publikacje

81 E. Repucho, Typografia kompletna. Kultura książi w twórczości Leona Urbańskiego, Wrocław 2016.

82 A. Chamera-Nowak, Roman i Andrzej Tomaszewscy w niewoli książek, [w:] W poszukiwaniu odpowiedniej formy. Rola wydawcy, typografa, artysty i technologii w pracy nad ksiąika, pod red. M. Komzy, Wrocław 2012, s. 217-231; K. Krzak-Weiss, Powrót do przeszłości. Inspiracje dawna książka we współczesnej typografii, [w:] W poszukiwaniu odpowiedniej formy..., s. 233-245.

83 A. Tomaszewski, Architektura książki dla wydawców, redaktorów, poligrafów, grafików, autorów, księgoznawców i bibliofilów, Warszawa 2011, s. 76-79; idem, O jedności treści, formy i funkcji [książi], [w:] idem, Zapiski ksiązkoroba, Warszawa 2006, s. 18-20.

84 Również tak podstawowe jak Słownik terminologiczny sztuk pięknych, Warszawa 1997.

85 J. Białostocki, Metoda ikonologiczna w badaniach nad sztuka, [w:] idem, Wybór pism estetycznych, Kraków 2008, s. 33-63.

86 E.H. Gombrich, Pisma o sztuce i kulturze, Kraków 2011; idem, Zmyst porzadku. O psychologii sztuki dekoracyjnej, Kraków 2009; R. Arnheim, Myślenie wzrokowe, tłum. M. Chojnacki, 
dotyczące technik graficznych i ich przygotowania technicznego ${ }^{87}$ oraz studia obejmujące analizę dzieł graficznych z różnych epok. Druki najstarsze, głównie renesansowe, omawiała Ewa Chojecka, o XVII wieku pisały Anna Treiderowa, Małgorzata Komza, Alicja Kurkowa, Irena Voisé-Maćkiewicz, Jadwiga Bednarska i Jolanta Talbierska, a o XVIII Ewa Łomnicka-Żukowska ${ }^{88}$. Równie ważna jest analiza materiału graficznego pod kątem ikonograficznym, przy czym skorzystać warto zarówno z materiałów historycznych (Ikonologia Cezarego Ripy ${ }^{89}$ ), jak i ze współczesnych opracowań. Szczególnie cenne są prace Stanisława Kobielusa, Dorothei Forstner i Lucyny Rotter ${ }^{90}$, opracowania z dziedziny emblematyki Ja-

Gdańsk 2011; idem, Sztuka i percepcja wzrokowa. Psychologia twórczego oka, tłum. J. Mach, Kraków [b.r.].

87 J. Werner, Technika i technologia sztuk graficznych, Kraków 1972; A. Krejča, Techniki sztuk graficznych. Podręcznik metod warsztatowych i historii grafiki artystycznej, Warszawa 1984; J.M. Szymański, Szlachetne techniki graficzne, cykl artykułów ukazujący się w czasopiśmie „Wydawca" w latach 1996-1998.

88 E. Chojecka, Deutsche Bibelserien in der Holzstocksammlung der Jagielonischen Universität in Krakau, Baden-Baden-Strasbourg 1961; eadem, Lukasz Cranach st. i krakowska grafika renesansowa, „Biuletyn Historii Sztuki” 34, 1972, nr 1, s. 23-29; eadem, Znaczenie kulturowe grafiki polskiej XVI wieku, [w:] Dawna książka i kultura. Materiaty międzynarodowej sesji naukowej z okazji pięćsetlecia sztuki drukarskiej w Polsce, pod red. S. Grzeszczuka i A. Kaweckiej-Gryczowej, Wrocław 1975, s. 86-114; eadem, Ilustracja polskiej ksiażki drukowanej XVI i XVII w., Warszawa 1980; eadem, Drzeworyty Kroniki Joachima Bielskiego i zaginione gobeliny Anny Jagiellonki: Ze studiów nad zwiazkami artystycznymi Krakowa i Brzegu w XVI wieku, „Roczniki Sztuki Śląskiej” 7, 1970, s. 37-73; A. Treiderowa, Ze studiów nad ilustracja wydawnictw krakowskich w wieku XVII (z drukarni Piotrkowczyków, Cezarych, Szedlów i Kupiszów), „Rocznik Biblioteki PAN w Krakowie" 14, 1968, s. 5-41; M. Komza, Ilustrowana książka gdańska w XVII wieku. Komunikat, „Sprawozdania Wrocławskiego Towarzystwa Naukowego” seria A, t. 29, 1974, s. 39-40; eadem, Zdobione karty tytułowe. Wprowadzenie do typologii na przykładzie siedemnastowiecznej książki gdańskiej, „Studia o Książce” 8, 1978, s. 51-68; A. Kurkowa, Grafika ilustracyjna gdańskich druków okolicznościowych XVII wieku, Wrocław 1979; I. Voisé-Maćkiewicz, Barokowe zdobnictwo druków toruńskich, „Roczniki Biblioteczne” 1957, nr 1/2, s. 67-78; J. Bednarska, Z dziejów polskiej ilustracji panegirycznej pierwszej połowy XVII wieku. Motywy i tematy antyczne w polskiej panegirycznej ilustracji ksiażkowej. Studium z zakresu ikonografi sztuki nowożytnej [Cz. 1], Katowice 1994 („Rozprawy i Studia Muzeum Śląskiego”); Cz. 2, Problematyka stylistyczno-formalna polskiej panegirycznej ilustracji książkowej, Katowice 2005; J. Talbierska, Grafika XVII wieku w Polsce. Funkcje, ośrodki, artyści, dzieła, Warszawa 2011; E. Łomnicka-Żakowska, Grafika polska XVIII wieku. Rytownicy polscy i w Polsce działajacy, Warszawa 2008.

89 C. Ripa, Ikonologia, Kraków 2002.

90 S. Kobielus, Człowiek i ogród rajski w kulturze religijnej średniowiecza, Warszawa 1997; idem, Bestiarium chrześcijańskie. Zwierzęta w symbolice i interpretacji. Starożytność i średniowiecze, Warszawa 2002; idem, Florarium christianum. Symbolika roślin - chrześcijańska starożytność i średniowiecze, Kraków 2006; idem, Krzyż Chrystusa. Od znaku i figury do symbolu i metafory, Tyniec 2010; idem, Lapidarium christianum. Symbolika drogich kamieni. Wczesne chrześcijaństwo i średniowiecze, Kraków 2012; D. Forstner, Świat symboliki chrześcijańskiej, Warszawa 2001; L. Rotter, Symbolika kwiatów i ziól, [w:] Symbolika roślin, pod red. J. Mareckiego i eadem, Kraków 2010, s. 75-88; eadem, Rośliny jako atrybuty świętych, [w:] Symbolika roślin..., s. $187-206$.

Roczniki Biblioteczne 61, 2017

(C) for this edition by CNS 
nusza Pelca i Pauliny Buchwald-Pelcowej ${ }^{91}$ oraz słowniki i leksykony zbierające znaczenie symboli i alegorii ${ }^{92}$. Połączenie wiedzy teoretycznej umożliwiającej analizowanie technik wykonania ilustracji i ich znaczenia oraz symboliki pozwala nie tylko lepiej zrozumieć skomplikowane relacje łączące tekst z ilustracją, ale również inaczej podejść do zagadnienia stylizacji (dobór odpowiednich typów grafiki do tekstu $\mathrm{z}$ danej epoki).

Funkcjonalne podejście do projektu sprawia, że jest on postrzegany całościowo. Połączenie kompetencji badacza książki dawnej i wrażliwości projektanta odkrywa nowe perspektywy: naukowiec może zauważyć w książce dawnej prócz świadectwa materialnego epoki także wytwór biegłego fachowca, a próba odtworzenia procesu projektowego może być inspirująca również dla dizajnera. Wspomniany już fakt, że wielcy teoretycy dizajnu i projektanci zainteresowani byli historią książki, nie jest przypadkowy. Jan Tschichold w swoich badaniach nad rękopisami dotarł do zasady złotego kanonu, co odbiło się także na jego pracach ${ }^{93}$, Robert Bringhurst w kanonicznym już opracowaniu przedstawił założenia projektów dawnych (proporcje, dobór krojów itp.), inspirując tym samym projektantów do sięgania po te środki. Równie interesujące zarówno dla projektantów, jak i dla badaczy mogą być prace innych teoretyków i historyków dizajnu: Alberta Kapra i Waltera Schillera, Josta Hochuliego, Beatrice Warde, Ellen Lupton, Kimberly Elam, Janusza Sowińskiego, Romana i Andrzeja Tomaszewskich oraz Krzysztofa Tyczkowskiego ${ }^{94}$.

91 J. Pelc, Obraz - Stowo - Znak. Studium o emblematach w literaturze staropolskiej, Wrocław 1973, s. 31-33 („Studia Staropolskie” 37); idem, Stowo i obraz na pograniczu literatury i sztuk plastycznych, Kraków 2002; P. Buchwald-Pelcowa, Emblematyka w późnobarokowych drukach polskich, „Biuletyn Historii Sztuki” 42, 1980, nr 3-4, s. 401-413; eadem, Emblematy $w$ drukach polskich i Polski dotyczacych XVI-XVIII wieku. Bibliografia, Wrocław 1981; eadem, Na pograniczu emblematów i stemmatów, [w:] Słowo i obraz. Materiały Sympozjum Komitetu Nauk o Sztuce PAN, Nieborów 29 września-1 października 1977 r., pod red. A. Morawińskiej, Warszawa 1982, s. 73-95; eadem, Typologia polskich ksiazzek emblematycznych, „Barok” 3, 1996, nr 1, s. 59-75; J. Pelc, P. Buchwald-Pelcowa, Rola Jezuitów w ksztaltowaniu się związów emblematyki polskiej z emblematyka niderlandzka, „Barok. Historia - Literatura - Sztuka” 10, 2003, nr 2 (20), s. 9-32.

92 W. Kopaliński, Słownik symboli, Warszawa 2001.

93 Także tłumaczone na polski: J. Tschichold, Prawidłowe proporcje stronicy i kolumny książki, „Poligrafika” 1966, nr 3, s. 70-77; idem, Typografia symetryczna czy asymetryczna?, „Poligrafika” 1966, nr 6, s. 142-143; idem, Formaty ksiazżek i ich proporcje, „Poligrafika” 1966, nr 7, s. $169-170$.

94 A. Kapr, W. Schiller, cykl artykułów w „Poligrafice” (1986-1990); J. Hochuli, R. Kinross, Designing Books. Practice and Theory, London 1996; B. Warde, The Crystal Goblet: Sixteen Essays on Typography, London 1955; E. Lupton, Thinking with Type, New York 2004; K. Elam, Geometry of Design. Studies in Proportion and Composition, New York 2001; eadem, Grid Systems: Principles of Organizing Type, New York 2004; eadem, Typographic Systems, New York 2007; R. Tomaszewski, Typografia ksiażki, „Poligrafika” 1962, nr 7, s. 23-24; idem, Cztery definicje, „Litera” 1967, nr 8, s. 123-128; idem, Pismo drukarskie a estetyka druku, Toruń 1983; A. Toma- 
Niekiedy dokonania i odkrycia epok młodszych pozwalają inaczej patrzeć na zjawiska dawniejsze. Wprowadzenie przez modernizm, a nade wszystko przez szwajcarską szkołę projektowania, pojęcia siatki modularnej (gridu) oraz modułu ${ }^{95}$ okazało się niezwykle inspirujące dla projektantów XX wieku. Jednak termin „moduł” pojawia się już w pismach Witruwiusza z I wieku p.n.e. Dokładniejsze przyglądnięcie się książce dawnej pozwala odkryć, że siatkę stosowano już co najmniej w średniowiecznych rękopisach ${ }^{96}$.

Połączenie zainteresowań badawczych dotyczących historii książki, a nawet szerzej, historii dizajnu czy historii sztuki, pozwala spojrzeć na projekt dawnej publikacji w nieco inny, może nawet pełniejszy sposób. Szersza perspektywa badań, porównująca konkretne rozwiązania, ale niebagatelizująca prądów estetycznych i teoretycznych rozważań o sztuce i dizajnie, może ukazać w innym świetle projekty z wcześniejszych epok, na które przyzwyczailiśmy się patrzeć w stały, pozbawiony pasji badawczej sposób. Okazać się mogą zaskakująco nowatorskie na tle swojej epoki lub też utworzą łańcuch ewolucyjny wzorów prowadzący od książki dawnej do nowoczesnego, w pełni współczesnego projektu. Co więcej, okazać się może, że rozwiązania dawne będą stanowić wzór i inspirację do tworzenia publikacji nowej generacji, także cyfrowych (w końcu e-book, książka bez stron, wraca do wcześniejszej formy, jaką był zwój). Jednocześnie projektant poznający ewolucję wszystkich elementów książki i typograficznych środków wyrazu bardziej świadomie korzysta z dziedzictwa swoich poprzedników i jest w stanie przetwarzać dawne wzory z zachowaniem ich historycznego kontekstu.

KLAUDIA SOCHA

\section{ON THE METHODOLOGY OF STUDYING OLD PRINTED BOOKS}

\section{Summary}

The article is an attempt to answer the question about the purpose of contemporary bibliological research into old books. In addition to strictly research-related assumptions concerning expansion of knowledge of old cultures and presentation of new perspectives, there are also prac-

szewski, Architektura książi, Warszawa 2011; idem, Leksykon pism drukarskich, Warszawa 1996; idem, Pismo drukarskie, Wrocław 1989; K. Tyczkowski, Lettera Magica, Łódź 2006.

95 Oprócz wspomnianej publikacji K. Elam: J. Müller-Brockmann, Grid Systems in Graphic Design. Rastersysteme für die visuelle Gestaltung, Sulgen-Zürich 1996; H.R. Bosshard, Der typografische Raster. The Typographic Grid, Sulgen-Zürich 2000; idem, Reguta i intuicja. O rozwadze i spontaniczności projektowania, Kraków 2017; M. Poradecki, Wykorzystanie linii pisma w projektowaniu książki, [w:] Wyzwania wspótczesnego edytorstwa, Wrocław 2010; R. Oleś, P. Sierżęga, Matematyka w stużbie typografii. Projektowanie na siatkach modułowych, „2+3D” 24, 2007, s. 32-38.

96 Zob. D. Byrne, Manuscript ruling and pictorial design in the work of the Limbourgs, the Bedford Master, and the Boucicaut Master, „The Art Bulletin” 66, 1984, nr 1, s. 118-136; J.H. Williamson, The grid: History, use, and meaning, „Design Issues” 3, 1986, nr 2, s. 15-30. 
tical considerations. The knowledge of the rules guiding type casters, typesetters and printers in the past may help modern designers of typefaces and publications in developing their skills. Adaptations, especially digital adaptations, of old typefaces require knowledge of old technologies; effective application of type as a means of expression is facilitated by knowledge of its historical determinants; while awareness of the evolution in book layout makes it possible to better design all elements of books.

Linking theoretical knowledge and practice may be inspiring not only for designers using old patterns, but also for scholars who, using the modern language of description and modern terminology, may see old books as designs in the fullness of their function.

KEY WORDS: methodology of studying old books, layout (design) of old books 